\title{
Garnet Peridotite Xenoliths from Kimberlites of Finland: Nature of the Lithospheric Mantle at Archaean craton - Palaeoproterozoic mobile belt transition
}

Peltonen, P. ', Huhma, $\mathrm{H}^{1}$, Tyni, $\mathrm{M}^{1}$., and Shimizu, N. ${ }^{2}$

1. Geological Survey of Finland, P.O. Box 96, FIN-02151 Espoo, Finland (petri.peltonen@gsf.fi)

2. Department of Geology and Geophysics, Woods Hole Oceanographic Institution, Woods Hole, MA 02543, USA

\section{Introduction}

At present, 24 kimberlites and related rocks have been located from the Eastern Finland Kimberlite Province (Fig. 1) where they occur as small - only half to four hectares in size - pipes and irregular dykes forming two separate clusters (Kuopio and Kaavi). Finnish kimberlites emplaced during the early Paleozoic being archetypal non-micaceous kimberlites, similar to those intruding Archaean cratons elsewhere ( $\mathrm{`}^{`}$ Brien and Tyni, this volume). Four of these pipes (\#5, 7, 9, 14), all consisting of serpentinised olivine tpicroilmenite -rich hypabyssal kimberlite and volcaniclastic diatreme facies rocks, were sampled for upper mantle xenoliths. The largest upper mantle xenolith measures $13 * 13 * 20 \mathrm{~cm}^{3}$ but most of them are well-rounded pebbles $(3-6 \mathrm{~cm}$ in diameter). This xenolith suite consists mainly of garnet-bearing peridotites which can be subdivided into coarse garnet-facies peridotites, which include harzburgites, lherzolites and wehrlites, and into granuloblastic garnetspinel facies peridotites which are all harzburgites. Less common mantle xenoliths include garnetolivine websterites and small bimineralic eclogites, some of them diamondiferous. None of the samples are akin to (mosaic-) porphyroclastic "sheared" xenoliths. This paper mainly discusses the chemical and isotopic composition of mantle xenoliths; alteration, oxygen fugacities and thermobarometry of the same samples are described in more detail elsewhere in this volume (Peltonen, 1998; Woodland \& Peltonen, 1998; Kukkonen \& Peltonen, 1998).

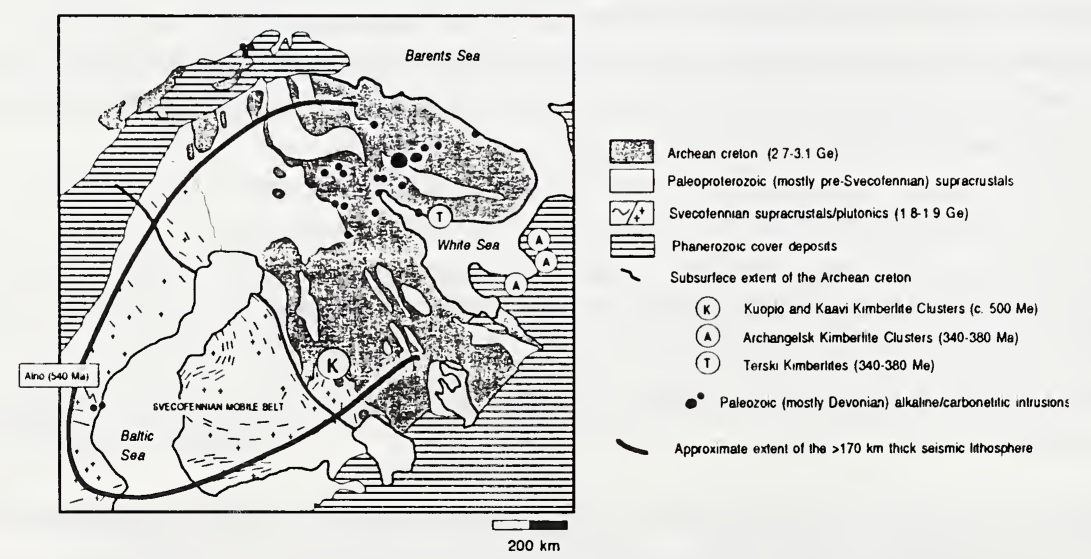

Fig. 1. Generalised geology of the eastern part of the Fennoscandian (formerly Baltic) Shield showing the locations and general geotectonic setting of the Finnish kimberlites (K). 


\section{Garnet facies peridotites}

Garnet facies xenoliths from the Finnish kimberlites are derived from the depth interval of 170-220 $\mathrm{km}$. Their major element compositions are broadly similar with low-temperature garnet peridotites from Kaapvaal and Siberian cratons. Low $\mathrm{Al}_{2} \mathrm{O}_{3}$ abundances coupled with pronounced LREEenrichment suggests that peridotites have been depleted in their basaltic constituents, but have been re-enriched in LREE (+ e.g. Rb, Th, K, Nb, Ta, P, Zr) subsequent to this depletion. Chondritenormalised rare earth patterns of all garnets - as determined by ion probe - are strikingly similar, being almost flat from $\mathrm{Yb}$ to Eu and showing the strong depletion of LREE relative to MREE and HREE that is typical for mantle garnets elsewhere. Clinopyroxenes also yielded highly uniform REE profiles that are convex-upward to weakly sinusoidal and peak at neodymium. Distribution of REE between gt and cpx follows published partitioning coefficients for that mineral pair implying that they are close to chemical equilibrium. Whole rock abundances for REE, as calculated from ion probe analysis by weighting with the modes, yielded slightly upward-convex but broadly chondritic patterns at levels of 0.3-1.3 times chondrite (Fig. 2). These patterns based on mineral data are distint from LREE-rich patterns measured on xenolith whole rock powders by ICP-MS, implying that most of the LREE in the xenoliths is present along grain boundaries and that within individual xenoliths garnet and clinopyroxene are not in chemical equilibrium with their host xenolith. Preservation of such disequilibrium, together with the absence of any correlation between size of the xenoliths and the intensity of metasomatism, imply that mantle xenoliths most probably have been infiltrated by LREE-enriched melt or fluid - most likely derived from the kimberlite itself - shortly before their detachment from the lithospheric mantle.

\section{Garnet-spinel facies peridotites}

Garnet-spinel facies peridotite xenoliths differ from the garnet facies samples in several important aspects. First, thermobarometry suggests that they are of significantly shallower $(90-130 \mathrm{~km})$ origin compared to garnet peridotites $(170-220 \mathrm{~km})$. Second, they are more depleted containing significantly less clinopyroxene but have experienced slightly higher degree of metasomatism compared to garnet facies xenoliths. In contrast to garnet peridotites which are free from hydrous phases, garnet-spinel facies peridotites contain trace amounts of phlogopite and amphibole (magnesio katophorite). Ion probe analyses imply that - unlike in the case of garnet peridotites garnets and clinopyroxenes are not in chemical equilibrium. Garnets are either extremely depleted in $\mathrm{REE}$ (all $\mathrm{REE} \leq 1 *$ chondrite), or resemble metasomatised garnets with sinusoidal patterns. Clinopyroxenes, which generally occur as small interstial grains, are extremely LREE-enriched with highly fractionated REE-patterns, and most likely represent a secondary, metasomatic phase.

\section{Implications}

The studied suite of xenoliths provide insight into the lithospheric mantle apparently stabilised and evolved in a complex tectonic setting because the sampled kimberlites intrude the outernmost edge of the "continental" late Archaean (3.1-2.6 Ga) craton adjacent to the "oceanic" Svecofennian (1.9-1.8 Ga) mobile belt (Fig. 1). Originally, this craton margin developed at c. $1.95 \mathrm{Ga}$, when the prolonged stretching and rifting of the Archaean SCLM and crust culminated in the formation of new oceanic basin and passive continental margin (Peltonen et al., 1998). Later, this passive margin was reworked and overthrusted at c. $1.9 \mathrm{Ga}$ as a result of the accretion of the Svecofennian island arc terrane. One of the major implications of this work is that the lithospheric mantle adjacent to such an ancient suture zone is compositionally stratified into, a shallow, strongly depleted (i.e. 
harzburgitic) garnet-spinel facies zone and into a lower, petrologically more diverse and more fertile, garnet facies mantle. Whole rock REE abundances, as deduced from the SIMS mineral data and modes, are consistent with garnet-spinel facies xenoliths representing harzburgitic residues metasomatised shortly before or during the eruption by kimberlite derived melt/fluid (Fig. 2). Garnet facies peridotites, however, represent truly distinct material. Their modal diversity (harzburgite-lherzolite-wehrlite), together with variable and low $\mathrm{Al}_{2} \mathrm{O}_{3}$ abundances would suggest that they represent peridotites depleted in their basaltic constituents to varying degrees. However, such an origin is inconsistent with their subparallel REE patterns (Fig. 2), because partial melting should produce preferential depletion of the LREE. Two models could explain such a decoupling between incompatible $\mathrm{Al}$ and REE. First, garnet peridotites could represent residual peridotites which had earlier been metasomatised to produce the observed relatively unfractionated REE distribution. This would, however, require intense and pervasive metasomatism by an agent having broadly chondritic REE. This possibility is considered improbable. A more likely possibility is that garnet-facies peridotites actually originally formed as ultramafic cumulates from (mafic-)ultramafic melts with broadly chondritic REE distribution. This would explain both the coexistence of unfractionated $\mathrm{REE}$ patterns with low and variable $\mathrm{Al}_{2} \mathrm{O}_{3}$ abundances (both being controlled by the amount of trapped melt in the cumulates) as well as the modal diversity of garnet peridotites (reflection of primary igneous layering). Further, it is probable that the eclogites, which have similar REE patterns as the garnet peridotites (but at higher levels), represent the mafic cumulates of the same melts.

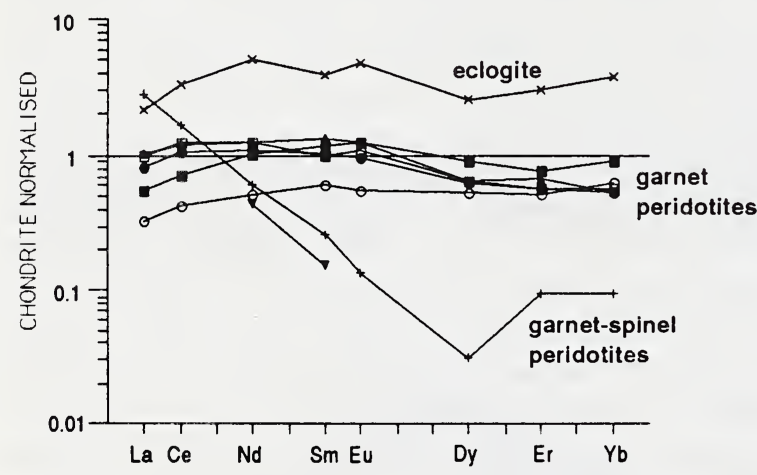

Fig.2. Chondrite-normalised rare earth element patterns for representative garnet peridotites, garnetspinel peridotites and a mantle eclogite. These patterns were obtained by weighting the REE abundances of garnets and clinopyroxenes, as determined by SIMS, by the mineral modal abundances within each sample.

Because the model presented for the formation of this former passive continental margin requires extensive thinning of the Archaean SCLM during continental break-up, and its partial replacement by suboceanic lithosphere during the early Proterozoic, it is quite probable that at the site of the kimberlites the lithospheric mantle is actually also age stratified. In such a scenario, the shallow garnet-spinel facies peridotites could represent remnants of the Archaean SCLM while the garnet facies peridotites of deeper origin represent Proterozoic additions of possible cumulate origin.

\section{References}

Peltonen, P., Kontinen, A., and Huhma, H., 1998, Petrogenesis of the mantle sequence of the Jormua Ophiolite (Finland): melt migration in the upper mantle during Palaeoproterozoic continental break-up. J. Petrol., v. 39(2), in press.

O`Brien, H.E., and Tyni, M., 1998, Mineralogy and geochemistry of kimberlites and related rocks from Finland. This volume. 